\title{
Air Pollution Index and Inhalation Risk Assessment to Carbon Monoxide and Nitrogen Dioxide to Traders in the bus station
}

\author{
Deddy Alif Utama ${ }^{1}$, Anwar Daud ${ }^{2}$, Masni $^{3}$ \\ \{dau475@umkt.ac.id ${ }^{1}$, anwardaud66@gmail.com ${ }^{2}$, masnimappajanci@ rocketmail.com ${ }^{3}$ \} \\ Environmental Health Department of Universitas Muhammadiyah Kalimantan Timur ${ }^{1}$ \\ School of Public Health of Hasanuddin University ${ }^{2,3}$
}

\begin{abstract}
In addition to decreasing air quality, carbon monoxide (CO) and nitrogen dioxide $\left(\mathrm{NO}_{2}\right)$ gases also have a major impact on the deterioration of human health. Air pollution index (API) was investigated as well as the potential health risk from the exposure of carbon monoxide and nitrogen dioxide to traders in Malengkeri bus station, Indonesia. Samples were collected by purposive sampling technique. The results revealed that air pollution index of $\mathrm{CO}$ and $\mathrm{NO}_{2}$ at the beginning of the week were 1473.82 and 2.57 , respectively. While on the weekend were 2874.83 and 1.53 , respectively. The average risk quotient of acute exposure at the beginning of the week for $\mathrm{CO}$ was 0.0036 . While on the weekend was 0.0041 . The average risk quotient of chronic exposure at the beginning of the week for $\mathrm{NO}_{2}$ was 0.02 . While on the weekend was 0.01 . The air pollution index of $\mathrm{CO}$ from the beginning until the end of the week could be described as a danger for human health, while for $\mathrm{NO}_{2}$ was good. Both average risk quotient of $\mathrm{CO}$ and $\mathrm{NO}_{2}$ had not exceeded the guideline $(>1)$ and not indicated any noncarcinogenic health risk. However, the male might suffer from the effect compared with female.
\end{abstract}

Keywords: $\mathrm{CO}, \mathrm{NO}_{2}$, Traders

\section{Introduction}

Air pollution is a multifaced mix consisting of suspended particulates and gaseous pollutants [1]. The increase in human population, industrialization, urbanization, and modernization are significant contributors to the rising urban air quality problem [2]. In many areas, decreasing ambient air quality cannot be separated from the significant increase in vehicles. Statistical data showed the number of vehicles in Makassar, Maros, Sungguminasa, and Takalar (Mamminasata) of South Sulawesi, Indonesia has increased in the last three years. Although the trend of vehicles that pass the emission test in three monitoring periods (2007 2011) have shown the continues to increase $(50 \%$ to $80 \%)$, however, ambient air quality still has parameters with an average concentration exceeding the quality standard, namely $\mathrm{HC}$ which is two times higher than the standard quality value in 2012 [3]. Vehicle emission has also become the dominant source of various air pollutants, including carbon monoxide (CO), carbon dioxide $\left(\mathrm{CO}_{2}\right)$, volatile organic compounds (VOCs), nitrogen oxide $\left(\mathrm{NO}_{\mathrm{X}}\right)$, and particulate matter (PM) [4]. These emissions continue to be a major environmental problem and contribute to risks of morbidity and mortality for drivers, commuters, and individuals living near roadways [5],[6]. 
Among some pollutant that comes from vehicles, carbon monoxide is one of the most dangerous from others. CO has classified as the 'respiratory pollutant' sub-group 'asphyxiants,' which is a pollutant that has an impact or effect on the respiratory and circulatory systems [7]. The amount of $\mathrm{CO}$ in the air by $0.032 \%$ comes from incomplete combustion. When running, $\mathrm{CO}$ gas produced in a gasoline engine is around $1 \%$ and $7 \%$ when not running. While diesel engines produce $\mathrm{CO}$ in the air by $0.2 \%$ when running and $4 \%$ when not running [8]. However, even at much lower doses typically found in outdoor air, numerous studies have found an association between short-term variation in outdoor $\mathrm{CO}$ levels and increased risk of cardiovascular morbidity and mortality [9],[10] Who set guideline values for CO, a 1-hour level of $30 \mathrm{mg} / \mathrm{m}^{3}$, and an 8 -hour level of $10 \mathrm{mg} / \mathrm{m}^{3}[11]$.

In addition to the existence of $\mathrm{CO}$ as a dangerous pollutant substance, in urban air, $\mathrm{NO}_{2}$, a secondary air pollutant which is also quite dangerous for human health, is mostly derived from local vehicular traffic through the oxidation of $\mathrm{NO}$ by $\mathrm{O}_{2}$ in the atmosphere [12]. $\mathrm{NO}_{2}$ is a highly reactive oxidant and corrosive, but it also a good surrogate indicator of traffic generated pollutant. $\mathrm{NO}_{2}$ acts mainly as an irritant affecting the mucosa of the eyes, nose, throat, respiratory tract, and development of acute or chronic bronchitis [13]. Given the adverse health effect of $\mathrm{NO}_{2}$, WHO set guideline values for $\mathrm{NO}_{2}$, a 1-hour level of $200 \mu \mathrm{g} / \mathrm{m}^{3}$ and 24hour level of $40 \mu \mathrm{g} / \mathrm{m}^{3}[12]$.

At present, public transport and its infrastructure are still a common feature of urban transportation in a developed and developing the country. But, the state of public transport in the cities of the developing countries differs widely from those of the developed countries [14],[15]. Public transport and its infrastructure in Makassar as one of the big cities in Indonesia is regarded as poorest in the world. There is no rail way of transit service as one of the alternative modes of transportation for the community. Thus, transportation mode in Makassar commonly refers to the motorcycle, microbus, and taxi. The city's public microbus lines suffer from an absence of effective regulations, which means there are no official microbus stops, and drivers can stop anywhere to let people on and off. Even in some cases, because the lack of facilities and the absence of specific regulations about vehicles, the bus station is not only used as a special transit site for buses but also used for other types of vehicles such as microbuses. It resulted in the more dense pollutant bus station and will impact all community, including traders.

\section{Materials and methods}

\subsection{Study area overview and human samples}

All pollutant $\left(\mathrm{CO}\right.$ and $\left.\mathrm{NO}_{2}\right)$ were collected as risk agents of vehicles emission on June $19^{\text {th }}$ July $25^{\text {th, }} 2015$ at Malengkeri Bus Station. Figure 1 shows the study area location. Considering the factors such as traffic flow rate, amount of vehicle, term of operation, sampling condition, eight sampling sites were selected through two measurement, in the beginning of the week (Monday - Wednesday) and on weekend (Friday - Sunday), including one in station entrance, one in station exit, four in the bus/minibus parking lot, two at the bus stop. Each risk agent in sampling site was measured three times a day for 1-hour measurement (morning, afternoon, and evening). The data obtained was used to calculate the air pollution index and inhalation risk assessment. The human samples which amounted to 58 people in this study were traders who worked during the bus station operating hours and were determined based on two criteria, 
(1) having worked for at least 1 year in the bus station area and (2) willing to participate in this study.

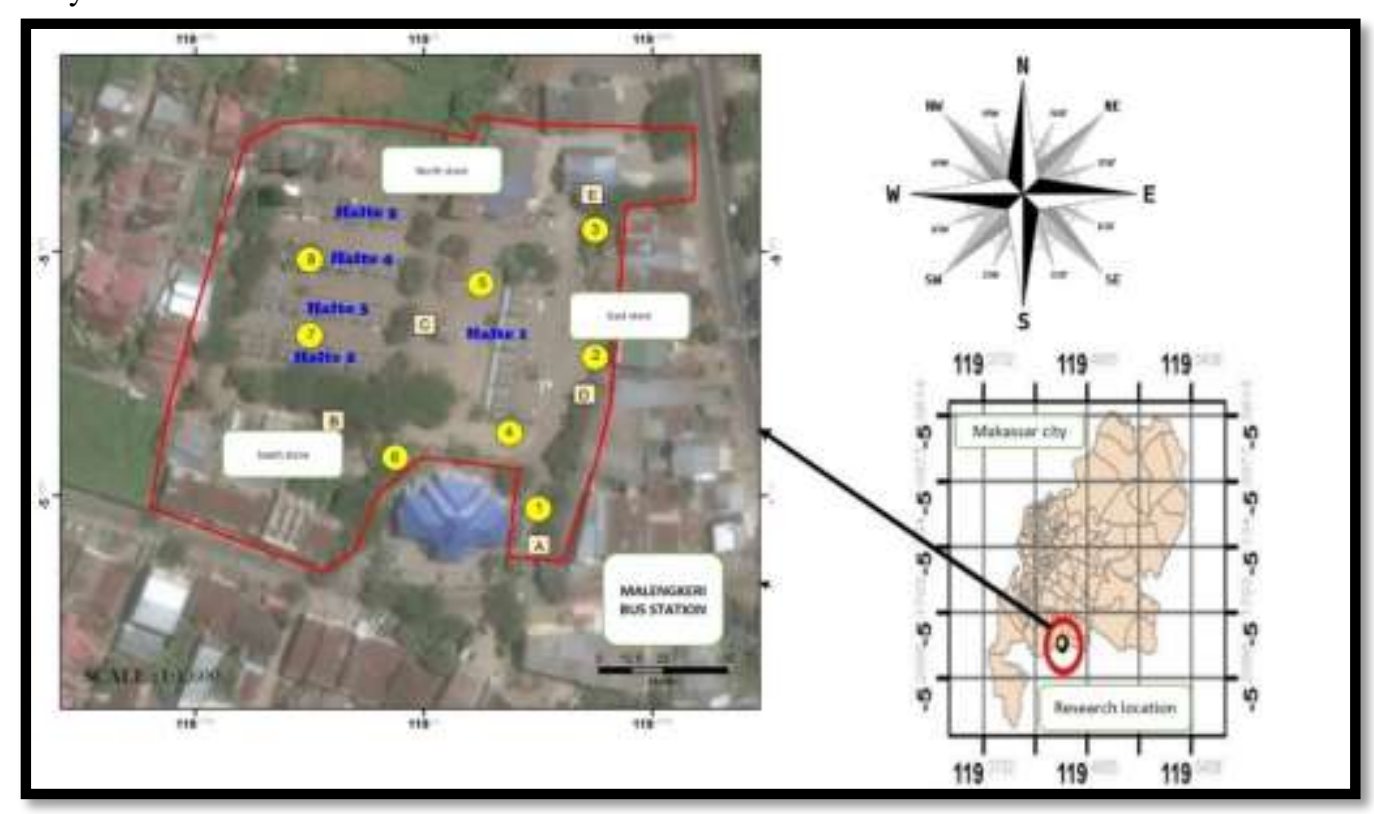

Fig 1. Study Area Location (1 - 8 sampling site; $A=$ station entrance, $B, C, D=$ bus/minibus parking site, $\mathrm{E}=$ station exit)

\subsection{Sampling and analysis methods}

\section{Footnotes and acknowledgments}

Air sampling. In this study, $\mathrm{CO}$ concentration in the air was determined by non-dispersive infrared (NDIR) method. While $\mathrm{NO}_{2}$ concentration was determined by the Griess Saltzman method using impinge sampling technique and spectrophotometric measurement. Collected air sample was used to determine air pollution index (API) and inhalation risk assessment of traders. However, at the time of field measurement, the measurement time required for data retrieval is sometimes not by the measurement time specified in the quality standard, for example, carbon monoxide. Carbon monoxide was collected within 1-hour measurement in the field, while in the quality standard used 8-hours measurement. This can be anticipated by estimating the measurement time in the field with the measurement time by the quality standard by using the Canter constant in the mathematical expression (1) below:

$$
\mathrm{C}_{1}=\mathrm{C}_{2}\left(\frac{\mathrm{t}_{2}}{\mathrm{t}_{1}}\right) \mathrm{p}(1)
$$

Where, $\mathrm{C}_{1}=$ average concentration of air pollutants with measurement time based on quality standards $\left(\mu \mathrm{g} / \mathrm{m}^{3}\right) ; \mathrm{C}_{2}=$ average concentration of air pollutants based on field measurement time $\left(\mu \mathrm{g} / \mathrm{m}^{3}\right) ; t_{2}=$ average time based on field measurement(hours); $t_{1}=$ average time based on quality standard (hours); $\mathrm{p}=$ canter constant $(0.186)$. 


\section{Air pollution index}

API measurement was used to determine daily air pollution index of the pollutant for which EPA has to establish National Air Quality Standards (NAAQS) with an epidemiological function to determine a descriptor of human health effect due to short-term exposure ( 24 hour or less) [6]. The measurement was adopted in the decree of the Head of the Indonesian Environmental Impact Management Agency and contained:

1. Individual air pollution indexes and their corresponding concentration limits

Table 1. Individual Air Pollution Indexes and Their Corresponding Concentration Limits

\begin{tabular}{cccccc}
\hline Index & $\begin{array}{c}* \mathrm{PM}_{10} \\
(24 \text { hours })\end{array}$ & $\begin{array}{c}* \mathrm{SO}_{2} \\
(24 \text { hours })\end{array}$ & $\begin{array}{c}* \mathrm{CO} \\
(8 \text { hour })\end{array}$ & $\begin{array}{c}* \mathrm{O}_{3} \\
(1 \text { hour })\end{array}$ & $\begin{array}{c}* \mathrm{NO}_{2} \\
(1 \text { hour })\end{array}$ \\
\hline 50 & 50 & 80 & 5 & 120 & $* *$ \\
100 & 150 & 365 & 10 & 235 & $* *$ \\
200 & 350 & 800 & 17 & 400 & 1130 \\
300 & 420 & 1600 & 34 & 800 & 2260 \\
400 & 500 & 2100 & 46 & 1000 & 3000 \\
500 & 600 & 2620 & 57.5 & 1200 & 3750 \\
\hline
\end{tabular}

$* \mu \mathrm{g} / \mathrm{m}^{3}$

** There is no index can be reported at low concentrations with short-term exposure

2. The health impact of air pollution index

Table 2. Health impact of air pollution index

\begin{tabular}{ccl}
\hline Index & Categories & \multicolumn{1}{c}{ Impact } \\
\hline $1-50$ & Good & $\begin{array}{l}\text { Does not have a significant health impact on the human bodies, animals, } \\
\text { plants, constructions, and value of esthetic. } \\
\text { Does not have a significant health impact on the human bodies or } \\
\text { animals but affect sensitive plants, construction, and value of esthetic. }\end{array}$ \\
$\begin{array}{l}\text { Detrimental to human health and affect sensitive animals, plants, } \\
\text { constructions, and value of esthetic. }\end{array}$ \\
$\begin{array}{c}\text { Harmful in some segments of the population } \\
200-100\end{array}$ & $\begin{array}{l}\text { Very unhealthy } \\
\text { Hazardous }\end{array}$ & \begin{tabular}{l} 
Harmful in all segments of the population \\
\hline
\end{tabular}
\end{tabular}

Both API of $\mathrm{CO}$ and $\mathrm{NO}_{2}$ were calculated using the mathematical expression (2) and would be compared using the value in table 1 :

$$
I p=\frac{I_{H i}-I_{L o}}{B P_{H i}-B P_{L o}}\left(C_{P}-B P_{L o}\right)+I_{L o}
$$

Where, $\mathrm{I}_{\mathrm{p}}=$ the index value for pollutant $\mathrm{P} ; \mathrm{C}_{\mathrm{P}}=$ the truncated concentration of pollutant, $\mathrm{P}$; $\mathrm{BP}_{\mathrm{Hi}}=$ the break site that is $\geq \mathrm{C}_{\mathrm{P}}$; $\mathrm{BP}_{\mathrm{Lo}}=$ the break site that is $\leq \mathrm{C}_{\mathrm{P}}$; $\mathrm{I}_{\mathrm{Hi}}=$ the AQI value corresponding to $\mathrm{BP}_{\mathrm{Hi}}, \mathrm{I}_{\mathrm{Lo}}=$ the $\mathrm{AQI}$ value corresponding to $\mathrm{BP}_{\mathrm{Lo}}$ 


\section{Inhalation risk assessment}

Inhalation risk assessment methods of the U.S. Environmental Protection Agency (EPA)[17] was used to estimate health risk through inhalation pathway for two kinds of people (adult male and adult female). Because $\mathrm{CO}$ had an acute effect if inhaled more than $500 \mathrm{ppm}$ for 1 hour[18],[19], then the individual intake of acute exposure rate for CO, calculated as an hourly dose, not daily dose using the mathematical expression $(3)^{(2)}$ :

$$
A H D=C \times \frac{I R}{W_{b}}(3)
$$

Where $\mathrm{AHD}=$ the average hourly dose for inhalation $(\mu \mathrm{g} / \mathrm{kg} / \mathrm{hour}) ; \mathrm{C}=$ the concentration of the chemical $\left(\mu \mathrm{g} / \mathrm{m}^{3}\right) ; \mathrm{IR}=$ the inhalation rate $\left(\mathrm{m}^{3} /\right.$ hour $) ; \mathrm{W}_{\mathrm{b}}=$ the body weight $(\mathrm{kg})$. While individual dose for chronic daily exposure pollution of $\mathrm{NO}_{2}$, calculated using the mathematical expression (4)[20]:

$$
A D D=\frac{C \times I R \times t_{E} \times f_{e} \times D_{t}}{W_{b} \times t_{\text {avg }}}
$$

Where, $\mathrm{ADD}=$ the average daily dose $(\mathrm{mg} / \mathrm{kg}$-day) $\mathrm{C}=$ the average concentration of air pollutant $\left(\mathrm{mg} / \mathrm{m}^{3}\right) ; \mathrm{IR}=$ the average values of inhalation rate $\left(\mathrm{m}^{3}\right.$,day or $\mathrm{m}^{3}$ hour; male $=0.79$ $\mathrm{m}^{3} /$ hour, female $=0.59 \mathrm{~m}^{3} /$ hour) $[21] ; \mathrm{t}_{\mathrm{E}}=$ the average daily exposure time (hours/day); $\mathrm{f}_{\mathrm{E}}=$ the average exposure frequency (days/year); $\mathrm{D}_{\mathrm{t}}=$ the average exposure duration (years); $\mathrm{W}_{\mathrm{b}}$ $=$ the average weight $(\mathrm{kg}) ; \mathrm{t}_{\mathrm{avg}}=$ the average time period $(30 \times 365$ days for noncarcinogenic; $70 \times 365$ days for carcinogenic).

After calculated average daily dose, the risk quotient (RQ) approach used the assumption of dose additivity to assess the noncancer health effects from the data on the components. Risk Quotient (RQs) was normalized doses or exposure levels of the components and consist of the ratios of the exposure doses or exposure levels of a component to the health guidance values of the component, such as ATSDR's minimal risk levels (MRLs) or EPA's reference doses (RfDs)/reference concentration (RfCs). The health guidance value was the normalizing factor. If the RQ values did not exceed guidelines $(>1)$, it means not indicated any noncarcinogenic health risks. However, If the RQ values had exceeded the guideline $(>1)$, means indicated noncarcinogenic health risk for the whole lifespan. Noncarcinogenic RQ was calculated using the mathematical expression (5)[22]:

$$
R Q=\frac{A H D \text { or } A D D}{M R L \text { or } R f D \text { or } R f C \text { or } R E L}
$$

Except for RfC CO, each MRL or RfC pollutants were taken from a list issued by ATSDR and EPA. For example, RfC $\mathrm{NO}_{2}$ was $0.02 \mathrm{mg} / \mathrm{kg}$-day. RfC CO $\left(23 \mathrm{mg} / \mathrm{m}^{3}\right)$ was derived from the value of Office of the Environmental Health Hazard Assessment (OEHHAs) reference exposure level (RELs)[23], after being converted using equation (3) with average hourly dose equal to reference concentration $(\mathrm{AHC}=\mathrm{RfC})$, as follows:

$$
\begin{aligned}
R f C & =C \times \frac{I R}{W_{b}} \\
= & \frac{23 \frac{\mathrm{mg}}{\mathrm{m}^{3}} \times 0.69 \frac{\mathrm{m}^{3}}{\mathrm{hour}}}{57 \mathrm{~kg}} \\
& =0.27 \mathrm{mg} / \mathrm{kg} \text {-hour }
\end{aligned}
$$

Inhalation rate used as a standard in this study set by China's ministry of environment $\left(0.69 \mathrm{~m}^{3} /\right.$ hour$)[21]$ with an average body weight of traders as a sample. The value of China 
inhalation rate was closed to the inhalation rate used in several studies in Indonesia although there was a difference in body weight by $5.2 \%$ of the average body weight of Indonesians [24], [25], [26]. Therefore, RfC of carbon monoxide and nitrogen dioxide used in this study were $0.27 \mathrm{mg} / \mathrm{kg}$-hour and $0.02 \mathrm{mg} / \mathrm{kg}$-day, respectively.

\section{Results and discussion}

\subsection{Pollutant concentration.}

Air sampling concentration (carbon monoxide and nitrogen dioxide) were shown in Table 3. Air samples were collected within 1-hour measurement. For carbon monoxide level across all the station area at the beginning of the week, sampling site 4 had the highest average concentration $\left(522.21 \mu \mathrm{g} / \mathrm{m}^{3}\right)$ with a maximum value of $812.19 \mu \mathrm{g} / \mathrm{m}^{3}$ while the least was obtained in sampling site $1\left(244.16 \mu \mathrm{g} / \mathrm{m}^{3}\right)$ with a maximum value of $148.27 \mu \mathrm{g} / \mathrm{m}^{3}$. On the weekend, sampling site 4 was also recorded the highest average CO concentration $(814.64$ $\mu \mathrm{g} / \mathrm{m}^{3}$ ) with a maximum value of $1152.44 \mu \mathrm{g} / \mathrm{m}^{3}$. This value has increased by $56 \%$ when compared to the beginning of the week. Furthermore, sampling site 5 has recorded the lowest average $\mathrm{CO}$ concentration that is equal to $239.49 \mu \mathrm{g} / \mathrm{m}^{3}$ with a maximum value of 271.71 $\mu \mathrm{g} / \mathrm{m}^{3}$.

In terms of average concentration for nitrogen dioxide at the beginning of the week, sampling site 1 has the highest concentration $\left(20.24 \mu \mathrm{g} / \mathrm{m}^{3}\right)$ with a maximum value of 23.05 $\mu \mathrm{g} / \mathrm{m}^{3}$ while the lowest was obtained in sampling site $7\left(7.53 \mu \mathrm{g} / \mathrm{m}^{3}\right)$ with a maximum value of $11.11 \mu \mathrm{g} / \mathrm{m}^{3}$. On weekend, sampling site 3 was recorded the highest average $\mathrm{NO}_{2}$ concentration $\left(15.08 \mu \mathrm{g} / \mathrm{m}^{3}\right)$ with a maximum value of $27.03 \mu \mathrm{g} / \mathrm{m}^{3}$ while the least was also obtained in sampling site $7\left(6.75 \mu \mathrm{g} / \mathrm{m}^{3}\right)$ with a maximum value of $6.85 \mu \mathrm{g} / \mathrm{m}^{3}$. The average concentration of carbon monoxide and nitrogen dioxide in the beginning of the week for all sampling site were $333.95 \mu \mathrm{g} / \mathrm{m}^{3}$ and $14.54 \mu \mathrm{g} / \mathrm{m}^{3}$, respectively. While on weekend were $408.91 \mu \mathrm{g} / \mathrm{m}^{3}$ and $8.63 \mu \mathrm{g} / \mathrm{m}^{3}$, respectively.

Table 3. Pollutant concentration

\begin{tabular}{cccccccccc}
\hline \multirow{2}{*}{$\begin{array}{c}\text { Sampling } \\
\text { site }\end{array}$} & $\begin{array}{c}\text { Measurement } \\
\text { period }\end{array}$ & \multicolumn{9}{c}{ CO } & \multicolumn{3}{c}{ Concentration $\left(\mu \mathrm{g} / \mathrm{m}^{3}\right)$} & \multicolumn{3}{c}{$\mathrm{NO}_{2}$} \\
\cline { 3 - 10 } 1 & Min & Max & Mean & SD & Min & Max & Mean & SD \\
\hline \multirow{2}{*}{1} & BOW & 148.27 & 411.73 & 244.16 & 145.61 & 17.54 & 23.05 & 20.24 & 2.75 \\
& WKD & 449.83 & 644.39 & 571.84 & 106.29 & 9.91 & 16.31 & 12.13 & 3.61 \\
2 & BOW & 303.04 & 403.16 & 356.90 & 50.49 & 10.13 & 26.80 & 16.65 & 8.90 \\
& WKD & 622.91 & 1041.86 & 844.96 & 210.60 & 4.68 & 9.34 & 7.70 & 2.62 \\
\multirow{2}{*}{3} & BOW & 202.68 & 333.42 & 250.87 & 71.82 & 10.71 & 22.34 & 16.33 & 5.82 \\
& WKD & 235.27 & 1163.76 & 653.10 & 471.15 & 3.33 & 27.03 & 15.08 & 11.85 \\
4 & BOW & 334.48 & 812.19 & 522.21 & 254.73 & 15.83 & 20.65 & 17.86 & 2.49 \\
& WKD & 619.72 & 1152.44 & 814.64 & 293.69 & 2.55 & 14.81 & 8.46 & 6.14 \\
5 & BOW & 195.10 & 362.75 & 283.58 & 84.21 & 7.17 & 13.69 & 10.45 & 3.26 \\
& WKD & 220.78 & 271.71 & 239.49 & 28.01 & 2.68 & 5.60 & 4.45 & 1.55 \\
6 & BOW & 285.61 & 613.40 & 477.99 & 171.16 & 10.25 & 25.78 & 16.89 & 8.00 \\
& WKD & 168.41 & 385.63 & 263.99 & 110.92 & 4.45 & 8.36 & 5.76 & 2.25
\end{tabular}




\begin{tabular}{cccccccccc}
\multirow{2}{*}{7} & BOW & 207.23 & 361.20 & 273.43 & 79.21 & 4.69 & 11.11 & 7.53 & 3.27 \\
& WKD & 215.75 & 398.46 & 326.29 & 97.21 & 6.65 & 6.85 & 6.75 & 0.1 \\
\multirow{2}{*}{8} & BOW & 233.78 & 436.52 & 341.61 & 101.98 & 6.49 & 15.68 & 10.36 & 4.76 \\
& WKD & 226.30 & 419.36 & 325.35 & 96.62 & 4.38 & 13.30 & 8.69 & 4.46 \\
\multirow{2}{*}{ Total } & BOW & 148.27 & 812.19 & $333.95^{*}$ & 151.11 & 4.69 & 26.80 & 14.54 & 6.22 \\
& WKD & 168.41 & 1163.76 & $408.91^{*}$ & 300.97 & 2.55 & 27.03 & 8.63 & 5.52 \\
\hline
\end{tabular}

BOW $=$ Beginning of the week

$\mathrm{WKD}=$ Weekend

\subsection{Air pollution index}

In terms of air pollution index (API) showed in table 4, the variation across all sampling sites revealed that the average concentration of carbon monoxide was highly enough and increased by $47.2 \%$ from $233.55 \mu \mathrm{g} / \mathrm{m}^{3}$ to $342.98 \mu \mathrm{g} / \mathrm{m}^{3}$ during the beginning of the week to the weekend. Although both average concentrations have not passed the level of national air pollution standards, this increase has caused average air pollution index in the bus station area also increased significantly by $95.3 \%$ from 1473.82 to 2874.83 . This condition has been categorized as hazardous. In contrast, the average concentration of nitrogen dioxide from the beginning of the week had shown low concentration if compared with national air pollution standards and decreased by $41.3 \%$ on the weekend. Thus, the air pollution index for both measurement periods also shows good conditions. When viewed based on sampling sites (Figures 2 and Figure 3), the standard values of air pollutant index for carbon monoxide parameters at sampling site 1-4 were increased during the weekend when compared to the beginning of the weekOn the contrary, for sampling sites $5-8$, it was decreased. The highest value at the beginning of the week came from sampling site 4 (2972.56), while the lowest came from sampling site 8 (1464.92). On the weekend, the highest value came from sampling site 2 (4990.72), and the lowest came from sampling site 8 (1399.95). In general, all sampling sites were categorized as hazardous. For nitrogen dioxide, the value of the air pollutant index at each sampling site had decreased on the weekend. The value of air pollutant index at the beginning of the week was ranged between 1.33 - 3.58 and on the weekend were ranged between 0.79 - 2.67. In general, the whole site can be categorized as good.

Table 4. Air Pollution Index

\begin{tabular}{|c|c|c|c|c|c|c|}
\hline Parameter & $\begin{array}{c}\text { BOW } \\
\left(\mu \mathrm{g} / \mathrm{m}^{3}\right)\end{array}$ & API & Categories & $\begin{array}{c}\text { WKD } \\
\left(\mu \mathrm{g} / \mathrm{m}^{3}\right)\end{array}$ & API & Categories \\
\hline \multicolumn{7}{|c|}{ Carbon monoxide $(\mathrm{CO}) *$} \\
\hline Min & 165.84 & \multirow{4}{*}{1473.82} & \multirow{4}{*}{ Hazardous } & 162.67 & \multirow{4}{*}{2874.83} & \multirow{4}{*}{ Hazardous } \\
\hline Max & 354.71 & & & 573.93 & & \\
\hline Mean & 233.55 & & & 342.98 & & \\
\hline SD & 71.31 & & & 168.47 & & \\
\hline \multicolumn{7}{|c|}{ Nitrogen dioxide $\left(\mathrm{NO}_{2}\right) * *$} \\
\hline Min & 4.69 & \multirow{4}{*}{2.57} & & 2.55 & \multirow{4}{*}{1.53} & \multirow{4}{*}{ Good } \\
\hline Max & 26.90 & & $C_{3}$ & 27.03 & & \\
\hline Mean & 14.54 & & Good & 8.63 & & \\
\hline $\mathrm{SD}$ & 6.22 & & & 5.22 & & \\
\hline
\end{tabular}

* 8-hours measurement 


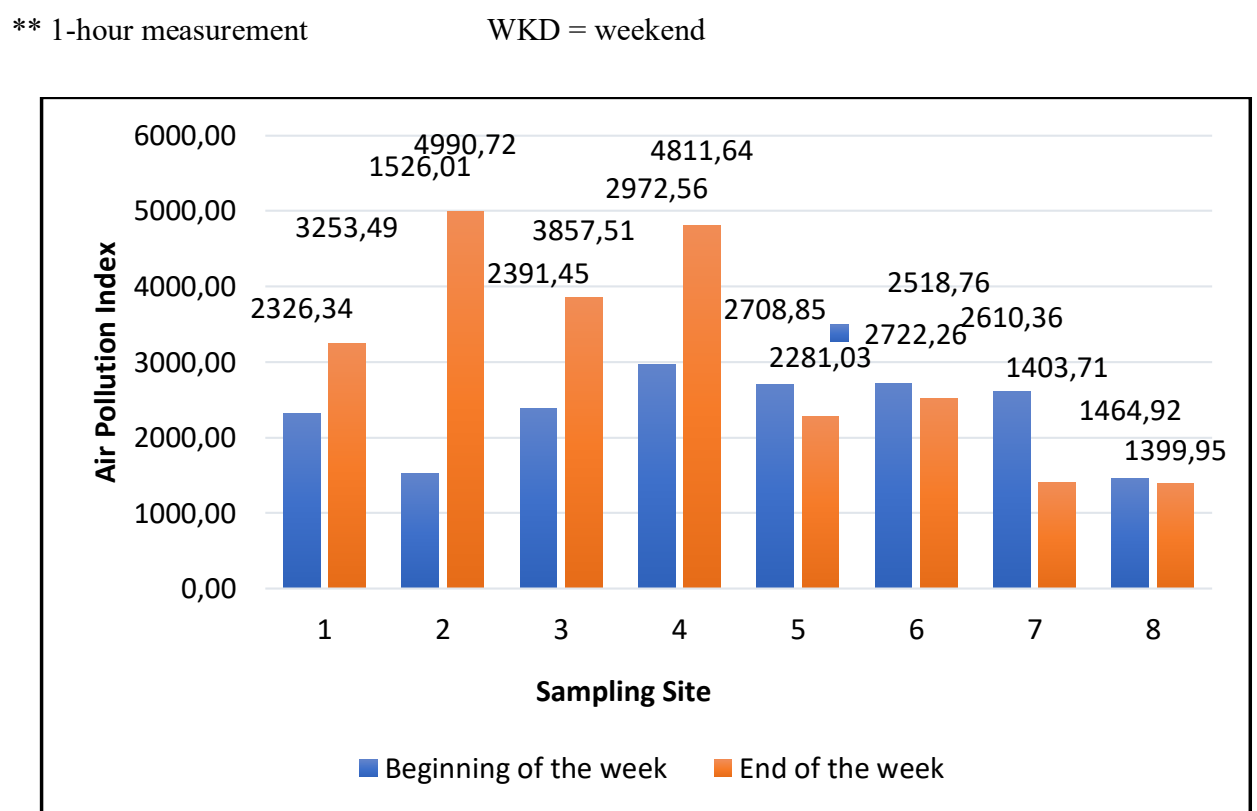

Fig 2. Air pollution index of carbon monoxide (CO) in sampling site

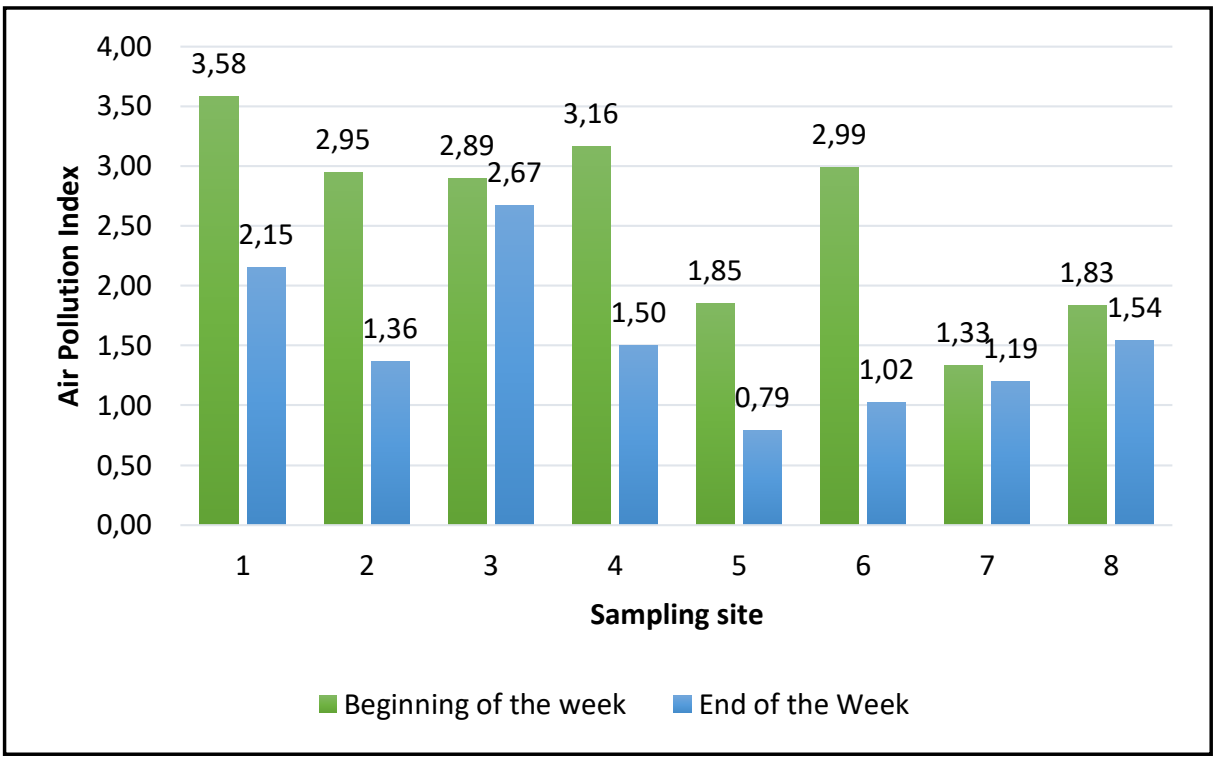

Fig 3. Air pollution index of nitrogen dioxide $\left(\mathrm{NO}_{2}\right)$ in sampling site 


\subsection{Anthropometric characteristics and exposure factors}

Summary of anthropometric variables value and patterns of respondent activity as exposure factors in the research location were listed in table 5. The average body weight of respondent was $56.6 \mathrm{~kg}$. This value was $24 \%$ lower than EPA's default body weight standard $(70 \mathrm{~kg})$. The average daily exposure time was 10.4 hours/day. This value was $0.3 \%$ higher than EPA's default daily exposure time for field worker ( 8 hours/day) but $56.7 \%$ higher than EPA's default daily exposure time for residential ( 24 hours/day). The average exposure frequency was 360.1 days/year, and the average exposure duration was 11.97 years.

Table 5. Average hourly and a daily dose of traders in the sampling site $(\mathrm{n}=58)$

\begin{tabular}{lcccc}
\hline \multicolumn{1}{c}{ Variable } & Min & Max & Mean & SD \\
\hline $\begin{array}{l}\text { Body weight }(\mathrm{Kg}) \\
\begin{array}{l}\text { Daily exposure time } \\
\text { (hours/day) }\end{array}\end{array}$ & 94 & 86 & 56.6 & 10.82 \\
$\begin{array}{l}\text { Exposure frequency } \\
\text { (days/year) }\end{array}$ & 310 & 11 & 10.4 & 0.528 \\
$\begin{array}{l}\text { Exposure duration } \\
\text { (year) }\end{array}$ & 1 & 363 & 360.1 & 9.224 \\
\hline
\end{tabular}

\subsection{Average hourly and a daily dose}

In terms of average hourly dose (AHD) and average daily dose (ADD) showed in table 6, the variation across all sampling sites at the beginning of the week revealed that the average hourly dose for carbon monoxide was ranged from $0.0026-0.0067 \mathrm{mg} / \mathrm{kg}$-hour with the highest value came from sampling site $4(0.0091 \mathrm{mg} / \mathrm{kg}$-hour $)$. While on the weekend was ranged from $0.0029-0.0082 \mathrm{mg} / \mathrm{kg}$-day with the highest value came from sampling site 2 $(0.0191 \mathrm{mg} / \mathrm{kg}$-day). For nitrogen dioxide at the beginning of the week, the average daily dose at each sampling site was ranged from $0.0001-0.0013 \mathrm{mg} / \mathrm{kg}$-day with the highest value came from sampling site $2(0.0031 \mathrm{mg} / \mathrm{kg}$-day $)$. While on the weekend was ranged from $0.0001-0.0006 \mathrm{mg} / \mathrm{kg}$-day with the highest value also came from sampling site $2(0.0014$ $\mathrm{mg} / \mathrm{kg}$-day).

Table 6. Average hourly and a daily dose of traders in the sampling site

\begin{tabular}{|c|c|c|c|c|c|c|c|c|c|}
\hline \multirow{3}{*}{ SP } & \multirow{3}{*}{ MP } & \multicolumn{4}{|c|}{ Average hourly dose (mg/kg-hour) } & \multicolumn{4}{|c|}{ Average daily dose (mg/kg-day) } \\
\hline & & \multicolumn{4}{|c|}{$\mathrm{CO}$} & \multicolumn{4}{|c|}{$\mathrm{NO}_{2}$} \\
\hline & & Min & Max & Mean & SD & Min & Max & Mean & SD \\
\hline \multirow{2}{*}{1} & BOW & 0.0022 & 0.0032 & 0.0027 & 0.0007 & 0.0006 & 0.001 & 0.0008 & 0.0002 \\
\hline & WKD & 0.0053 & 0.0075 & 0.0064 & 0.0015 & 0.0003 & 0.0006 & 0.0004 & 0.0001 \\
\hline \multirow{2}{*}{2} & BOW & 0.0029 & 0.0081 & $0.0035^{*}$ & 0.0018 & 0.00006 & 0.0031 & 0.0009 & 0.001 \\
\hline & WKD & 0.0069 & 0.0191 & $0.0082 *$ & 0.0042 & 0.00003 & 0.0014 & 0.0004 & 0.0004 \\
\hline \multirow{2}{*}{3} & BOW & 0.0023 & 0.0037 & $0.0026^{*}$ & 0.0004 & 0.00006 & 0.0004 & 0.0001 & 0.0001 \\
\hline & WKD & 0.0061 & 0.0096 & $0.0066^{*}$ & 0.0012 & 0.00005 & 0.0004 & 0.0001 & 0.0001 \\
\hline 4 & BOW & 0.0051 & 0.0091 & 0.0067 & 0.0013 & 0.00006 & 0.0025 & 0.0013 & 0.0009 \\
\hline
\end{tabular}




\begin{tabular}{cccccccccc} 
& WKD & 0.0079 & 0.0141 & 0.01 & 0.002 & 0.00003 & 0.0012 & 0.0006 & 0.0004 \\
5 & BOW & 0.0025 & 0.0055 & $0.0032^{*}$ & 0.0007 & 0.00009 & 0.001 & 0.0004 & 0.0002 \\
& WKD & 0.0021 & 0.0046 & 0.0029 & 0.0007 & 0.00008 & 0.0004 & 0.0002 & 0.0001 \\
6 & BOW & 0.0041 & 0.0067 & $0.0052^{*}$ & 0.0008 & 0.00015 & 0.0017 & 0.0009 & 0.0005 \\
& WKD & 0.0023 & 0.0037 & $0.0028^{*}$ & 0.0004 & 0.00005 & 0.0006 & 0.0003 & 0.0001 \\
7 & BOW & 0.0024 & 0.0038 & 0.0029 & 0.0005 & 0.00007 & 0.0006 & 0.0004 & 0.0002 \\
& WKD & 0.0029 & 0.0045 & 0.0035 & 0.0006 & 0.00006 & 0.0006 & 0.0003 & 0.0001 \\
8 & BOW & 0.0026 & 0.0044 & 0.0044 & 0.001 & 0.00009 & 0.0004 & 0.0002 & 0.0002 \\
& WKD & 0.0025 & 0.0042 & 0.0042 & 0.0009 & 0.00008 & 0.0004 & 0.0001 & 0.0001 \\
$\Sigma$ & BOW & 0.0022 & 0.0091 & $0.0036^{*}$ & 0.0016 & 0.00006 & 0.0031 & $0.0004 *$ & 0.0006 \\
& WKD & 0.0021 & 0.0191 & $0.0041^{*}$ & 0.0034 & 0.00003 & 0.0014 & $0.0002 *$ & 0.0002 \\
\hline
\end{tabular}

\footnotetext{
* Median

$\mathrm{MP}=$ Measurement period

$\mathrm{SP}=$ Sampling site

$\mathrm{BOW}=$ Beginning of the week

$\mathrm{WKD}=$ Weekend
}

\subsection{Average risk quotient and risk quotient cumulative}

Average risk quotient, according to gender, was shown in table 7. At the beginning of the week, the average risk quotient of $\mathrm{CO}$ for male in all sampling sites was 0.0053 , with the highest value came from sampling site $2(0.0081)$. While on the weekend was 0.0046 with the highest value also came from sampling site 2 (0.0191). For female, the average risk quotient of $\mathrm{CO}$ in all sampling site was 0.0035 , with the highest value came from sampling site 4 (0.006). On the weekend was 0.0041 with the highest value came from sampling site 2 (0.008). In general, average risk quotient of acute exposure at the beginning of the week for $\mathrm{CO}$ was 0.0036 . While on the weekend was 0.0041 . The measured average risk quotient of $\mathrm{NO}_{2}$ for male at the beginning of the week was 0.05 with the highest value came from sampling site $2(0.157)$, while on the weekend was 0.02 with the highest value came from sampling site 4 and 7 (Both were 0.03). For female, the average risk quotient at the beginning of the week was 0.02 with the highest value came from sampling site 4 . While on weekend was 0.01 with the highest value also came from sampling site 4 (0.03). In general, average risk quotient of chronic exposure at the beginning of the week for $\mathrm{NO}_{2}$ was 0.02 . While on weekend was 0.01 . The estimation of risk for acute and chronic exposure to $\mathrm{CO}$ and $\mathrm{NO}_{2}$ revealed that $\mathrm{RQ}<1.0$ for all population (male and female). This implied a negligible risk for all traders, both male and female. However, based on the results that have been explained previously, male may suffer from the effects compared with female. 
Table 7. Average Risk Quotients for traders in sampling site

\begin{tabular}{|c|c|c|c|c|c|c|c|}
\hline \multirow{3}{*}{ SP } & \multirow{3}{*}{ MP } & \multicolumn{6}{|c|}{ Risk Quotients } \\
\hline & & \multicolumn{3}{|c|}{$\mathrm{CO}$} & \multicolumn{3}{|c|}{$\mathrm{NO}_{2}$} \\
\hline & & Male & Female & Mean & Male & Female & Mean \\
\hline \multirow{2}{*}{1} & BOW & $0.0022^{*}$ & $0.0032 *$ & $0.0027 \pm 0.0007$ & $0.05^{*}$ & $0.03 *$ & $0.04 \pm 0.014$ \\
\hline & WKD & $0.0053^{*}$ & $0.0075^{*}$ & $0.0064 \pm 0.0015$ & $0.03^{*}$ & $0.018^{*}$ & $0.02 \pm 0.008$ \\
\hline \multirow{2}{*}{2} & BOW & $0.0081^{*}$ & $0.003 \pm 0.0003$ & $0.0035^{* *}$ & $0.157^{*}$ & $0.03 \pm 0.02$ & $0.049 \pm 0.05$ \\
\hline & WKD & $0.0191 *$ & $0.008 \pm 0.0008$ & $0.0082 * *$ & $0.07^{*}$ & $0.01 \pm 0.01$ & $0.02 \pm 0.02$ \\
\hline \multirow{2}{*}{3} & BOW & $0.0028 *$ & $0.002 * *$ & $0.0027 * *$ & $0.012 *$ & $0.009 \pm 0.007$ & $0.01 \pm 0.007$ \\
\hline & WKD & $0.0072 *$ & $0.006^{* *}$ & $0.0066 * *$ & $0.01^{*}$ & $0.008 \pm 0.007$ & $0.009 \pm 0.006$ \\
\hline \multirow{2}{*}{4} & BOW & $0.0066^{*}$ & $0.006 \pm 0.0015$ & $0.006 \pm 0.001$ & $0.06 \pm 0.02$ & $0.06 \pm 0.05$ & $0.06 \pm 0.04$ \\
\hline & WKD & $0.01 *$ & $0.01 \pm 0.0024$ & $0.01 \pm 0.002$ & $0.03 \pm 0.01$ & $0.03 \pm 0.02$ & $0.03 \pm 0.02$ \\
\hline \multirow{2}{*}{5} & BOW & $0.0055^{*}$ & $0.003 \pm 0.0004$ & $0.0032 * *$ & $0.02 *$ & $0.02 \pm 0.01$ & $0.02 \pm 0.01$ \\
\hline & WKD & $0.0046 *$ & $0.002 \pm 0.0005$ & $0.0027 * *$ & $0.01^{*}$ & $0.01 \pm 0.005$ & $0.01 \pm 0.005$ \\
\hline \multirow{2}{*}{6} & BOW & $0.0058 \pm 0.0006$ & $0.004 \pm 0.0006$ & $0.005 \pm 0.0008$ & $0.05 \pm 0.03$ & $0.04 \pm 0.02$ & $0.04 \pm 0.03$ \\
\hline & WKD & $0.0032 \pm 0.0003$ & $0.002 \pm 0.0003$ & $0.002 \pm 0.0004$ & $0.02 \pm 0.01$ & $0.01 \pm 0.008$ & $0.01 \pm 0.009$ \\
\hline \multirow{2}{*}{7} & BOW & $0.0032^{*}$ & $0.003 \pm 0.0005$ & $0.003 \pm 0.0005$ & $0.03^{*}$ & $0.018 \pm 0.01$ & $0.02 \pm 0.01$ \\
\hline & WKD & 0.0038 & $0.003 \pm 0.0007$ & $0.003 \pm 0.0006$ & $0.03 *$ & $0.02 \pm 0.009$ & $0.02 \pm 0.01$ \\
\hline \multirow{2}{*}{8} & BOW & NP & $0.0044^{* *}$ & $0.0044^{* *}$ & NP & $0.01 \pm 0.01$ & $0.01 \pm 0.01$ \\
\hline & WKD & NP & $0.0042 * *$ & $0.0042 * *$ & NP & $0.01 \pm 0.009$ & $0.01 \pm 0.009$ \\
\hline \multirow{2}{*}{$\Sigma$} & BOW & $0.0053 \pm 0.0018$ & $0.0035^{* *}$ & $0.0036 * *$ & $0.05 \pm 0.04$ & $0.02 * *$ & $0.02 * *$ \\
\hline & WKD & $0.0046 * *$ & $0.0041 * *$ & $0.0041 * *$ & $0.02 \pm 0.02$ & $0.01 * *$ & $0.01 * *$ \\
\hline & & $\begin{array}{l}\text { * Only one persol } \\
* * \text { Median } \\
\text { MP = Measureme } \\
\text { SP = Sampling si } \\
\text { NP = No person } \\
\text { BOW = Beginnin } \\
\text { WKD = Weekend }\end{array}$ & the week & & & & \\
\hline
\end{tabular}

Air pollution is now fully acknowledged to be a significant public health problem, responsible for a growing range of health effects that are well documented from the results of an extensive research effort conducted in many regions of the world[27]. Long-term effects of air pollution on the onset of diseases such as respiratory infections and inflammations, cardiovascular dysfunctions, and cancer is widely accepted; hence, air pollution is linked with millions of deaths globally each year[28]. Our finding revealed that $\mathrm{CO}$ concentration on weekends is much higher than at the beginning of the week. This is consistent with the several studies where air pollution on the weekend increases relatively higher than during working days. On weekends, most people go for a vacation and use vehicles such as motorcycle, car or public transport, resulting in increasing the number of vehicles on the road that has an impact on the increased concentration of pollutants. But this does not apply to certain types of 
pollutants[29-31]. For example, $\mathrm{NO}_{2}$ concentration has significantly decreased on the weekend. This contrasts with the results obtained for carbon monoxide. The low concentration of $\mathrm{NO}_{2}$ recorded in our study may be because $\mathrm{NO}_{\mathrm{x}}$ emission has started to decrease considerably around the world [32]. In the USA, surface $\mathrm{NO}_{2}$ level was decreased by $33 \%$ between 2001 and 2010 [33]. In Germany, $\mathrm{NO}_{\mathrm{x}}$ has decreased significantly since the mid-80s for about approximately $60 \%$. In East Asia, there has also been a decrease in $\mathrm{NO}_{2}$ concentration when compared to $\mathrm{CO}_{2}$ [34]. The overall decrease in concentration is due to several factors. Some of them are a significant reduction in the use of fossil fuels, distance from the highway and the speed of reaction in the formation of substances that is much slower when compared to other pollutants [34-36].

Carbon monoxide and nitrogen dioxide level in urban and industrial areas closely reflect traffic density (in combination with weather condition). In Germany, even has decreased significantly since the mid-80s, nitrogen oxide emissions are still largely caused by road traffic. Nationwide, the share of road transport in the total $\mathrm{NO}_{\mathrm{x}}$ emissions is currently around $60 \%$ [32]. A study in Nigeria revealed, the highest $\mathrm{CO}$ concentration was recorded at two major traffic intersection; this may be due to the high presence of vehicle during sampling[37]. This condition also occurs in this study during the process of measuring air samples. Because bus stations are not used specifically for buses, but public transport like minibus can enter the station to pick up passengers, there is a density of traffic flow inside the bus station ${ }^{[31]}$. Another study revealed that higher significant concentration of $\mathrm{CO}$ found at the bus station location. This higher level of some air pollutants may be due to the combustion of fuel types and idling buses[38]. Also, meteorological factors (temperature, humidity, and wind speed) have a positive correlation with the concentration of pollutants in the air [39].

In this study, air pollution index of both $\mathrm{CO}$ and $\mathrm{NO}_{2}$ gives different results according to the measurements of air concentration. The air pollution index of $\mathrm{CO}$ from the beginning until the end of the week could be described as a danger for human health, while $\mathrm{NO}_{2}$ can be described as good. It means that $\mathrm{CO}$ is harmful to all segments of the population including traders. While $\mathrm{NO}_{2}$ does not have a significant health impact on the human bodies. In health risk assessment approach, both average risk quotient of $\mathrm{CO}$ and $\mathrm{NO}_{2}$ had not exceed the guideline $(>1)$ and not indicated any noncarcinogenic health risk to traders. However, the male might suffer from the effect compared with female. As we know that $\mathrm{CO}$ and $\mathrm{NO}_{2}$ are dangerous pollutant which can have adverse health effects for humans and several studies have revealed it. Both pollutants can affect the respiratory system and cardiovascular system[40-42], . CO can cause acute vertigo, binds to hemoglobin in red blood cells, reducing their ability to transport and release oxygen throughout the body [19]. Moderate exposure of $\mathrm{CO}$ to the occupants along the study area can aggravate cardiac ailments such as the brain and heart[43]. While $\mathrm{NO}_{2}$ can cause asthma, and some study revealed that $\mathrm{NO}_{2}$ can caused cancer[44], [45],[46], [47]. Some of these health effects require a comprehensive approach and need quick and appropriate environmental management so that they do not cause adverse effects in the future. Some possible solutions that can be done are reducing the use of fossil fuels, using PPE if working in pollution-prone places and prioritizing the use of public transportation rather than private [48], [49], [50].

\section{Conclusion}

The study shows the air pollution index of CO from the beginning until the end of the week could be described as a danger for human health especially to traders, thus requiring environmental management quickly and appropriately by the government to reduce the health 
impacts that may arise while $\mathrm{NO}_{2}$ does not have a significant health impact on traders but still need to be maintained in the future. There is no health risk found to be associated with acute and chronic exposure to the pollutants through male and female traders, but for a male is more likely to suffer the health effects. Identification of the possibility of these pollutants will make valuable contributions to government and relevant stakeholders in taking more concrete steps to protect and prolong human lives. Additionally, these findings will assist policymakers in enforcing existing legislation that limits the release of pollutants into the atmosphere or institutes risk management strategies.

Acknowledgment. This study was supported by Universitas Muhammadiyah Kalimantan Timur and Hasanuddin University. Authors thank Environmental Health Department in both Universitas Muhammadiyah Kalimantan Timur and Hasanuddin University for providing valuable assistance during the study.

\section{References}

[1] Mustafić H, Jabre P, Caussin C, Murad MH, Escolano S, Tafflet M.: Main air pollutants, and myocardial infarction. a systematic review and meta-analysis. Jama. Vol. 307,pp. 713-21. ((2012)

[2] Morakinyo OM, Adebowale AS, Mokgobu MI, Mukhola MS.: Health risk of inhalation exposure to sub-10 $\mu \mathrm{m}$ particulate matter and gaseous pollutants in an urban-industrial area in South Africaan ecological study. BMJ open. Vol. 7, pp 9-17(2017)

[3] PPESUMAPAPUA. Environmental status of MAMMINASATA Ecoregions (Makassar, Maros, Sungguminasa and Takalar). (2013)

[4] NRC. The Congestion Mitigation and Air Quality Improvement Program. Assessing 10 Years of Experience. Transportation Research Board. Pp. 520 (2002)

[5] Zhang K, Batterman S.: Air pollution and health risks due to vehicle traffic. Science of the total Environment. Vol. 450, pp. 307-16. (2013)

[6] Lim SS, Vos T, Flaxman AD, Danaei G, Shibuya K, Adair-Rohani H.: A comparative risk assessment of burden of disease and injury attributable to 67 risk factors and risk factor clusters in 21 regions, 1990-2010 a systematic analysis for the Global Burden of Disease Study 2010. The lancet. Vol, 380. pp. 2224-60. (2012)

[7] McCracken JP, Wellenius GA, Bloomfield GS, Brook RD, Tolunay HE, Dockery DW,:Household air pollution from solid fuel use. Global Heart. Vol, 7. pp, 223. (2012)

[8] Damanik KY.: Analysis of Carbon Monoxide ( $\mathrm{CO}$ ) and Lead $(\mathrm{Pb})$ Concentration and Health Effect on Mechanical Motorbike Workshops in Medan Sunggal Subdistrict.North Sumatera University. Pp 9-20 (2017)

[9] Burnett RT, Cakmak S, Brook JR, Krewski D.: The role of particulate size and chemistry in the association between summertime ambient air pollution and hospitalization for cardiorespiratory diseases. Environmental health perspectives. Vol. 105, pp. 614. (1997)

[10] Bell ML, Peng RD, Dominici F, Samet JM.: Emergency hospital admissions for cardiovascular diseases and ambient levels of carbon monoxide. results for 126 United States urban counties, 19992005. Circulation. Vol. 120, pp. 949-55. (2009)

[11] WHO.: Air quality guidelines: global update 2005. World Health Organization. (2006)

[12] Abam F, Unachukwu G.: Vehicular emissions and air quality standards in Nigeria. European Journal of Scientific Research. Vol. 34, pp. 550-60. (2009)

[13] Larabee K, Phipatanakul W.: The Respiratory Health Effects of Nitrogen Dioxide in Children With Asthma. Pediatrics. Vol 130, pp. 56-60 (2012)

[14] Evren G, Akad M.: Transportation Planning Problems in Developing Countries. Department of Transportation, Technical University of Istanbul, Working Paper. pp. 143-800. (2001) 
[15] Zheng X, Zhao W, Yan X, Shu T, Xiong Q, Chen F.: Pollution characteristics and health risk assessment of airborne heavy metals collected from Beijing bus stations. International journal of environmental research and public health. Vol. 12,pp. 9658-71. (2015)

[16] Birnbaum R, Damberg R, Fitz-Simons T, Frank N, Freas W.: National air quality and emissions trends report, 1997. Environmental Protection Agency, Emissions, Monitoring, and Analysis Div.Research Triangle Park, NC (United States). pp. 67-90 (1998)

[17] Bennet D, Chang S, Cooper D, Dinan J, Hofmann E, Barry T,.: Risk Assessment Guidance for Superfund. Process for Conducting Probabilistic Risk Assessment. Washington: U, S. Environmental Protection Agency. Vol. 3, pp. 8-13 (2001)

[18] NRC.: Acute exposure guideline levels for selected airborne chemicals. National Academies Press. Pp. 9-18 (2009)

[19] Fierro MA, O'Rourke MK.: Burgess JL. Adverse health effects of exposure to ambient carbon monoxide. University of Arizona Report. 10-19(2001)

[20] Louvar JF, Louvar BD.: Health and environmental risk analysis: fundamentals with applications. Prentice Hall Upper Saddle River, NJ. (1998)

[21] Wang Z, Duan X, Liu P, Nie J, Huang N, Zhang J.: Human exposure factors of Chinese people in environmental health risk assessment. Research of Environmental Sciences. Vol. 22, pp.1164-75. (2009)

[22] Wilbur SB.: Guidance manual for the assessment of joint toxic action of chemical mixtures: Agency for Toxic Substances and Disease Registry. Pp. 15-19(2001)

[23] Hickox WH, Denton JE.: The Determination of Acute Reference Exposure Levels for Airborne Toxicants. (1999)

[24] Rahman A, Nukman A, Setyadi S, Akib CR, Sofwan S, Jarot J.: Environmental Health Risk Analysis of Limestone Mining in Sukabumi, Cirebon, Tegal, Jepara and Tulung Agung. Jurnal Ekologi Kesehatan.Vol.9. pp. 9-19(2008)

[25] Basri S, Bujawati E, Amansyah M.: Environmental Health Risk Analysis (Model for Measuring the Risk of Air Pollution Against Health). Jurnal Kesehatan. Vol. 7, pp.8-19(2014)

[26] Arista G, Sunarsih E, Mutahar R.: Health Risk Analysis of Nitrogen Dioxide $\left(\mathrm{NO}_{2}\right)$ and Sulphur Dioxide $\left(\mathrm{SO}_{2}\right)$ Exposure to Street Vendors at Palembang Ampera Terminal in 2015. Jurnal Ilmu Kesehatan Masyarakat.Vol. 6, pp. 15-25 (2015)

[27] Kelly FJ, Fussell JC.: Air pollution and public health. Emerging hazards and improved understanding of risk. Environmental geochemistry and health. Vol. 37, pp. 631-49. (2015)

[28] Ghorani-Azam A, Riahi-Zanjani B, Balali-Mood M.: Effects of air pollution on human health and practical measures for prevention in Iran. Journal of research in medical sciences. The official journal of Isfahan University of Medical Sciences.Vo.5 pp. 6-17. (2016)

[29] Shang J, Zheng Y, Tong W, Chang E, Yu Y.: Inferring gas consumption and pollution emission of vehicles throughout a city. Proceedings of the 20th ACM SIGKDD international conference on Knowledge discovery and data mining. Pp. 78 (2014)

[30] Davis LW.:The effect of driving restrictions on air quality in Mexico City. Journal of Political Economy. Vol. 116. Pp. 38-81. (2008)

[31] Utama DA, Daud A, Masni.: The Risk Assessment due to the Exposure of $\mathrm{CO}$ and $\mathrm{NO}_{2}$ in the Traders in Malengkeri Terminal Area. Makassar City. International Journal of Sciences. Basic and Applied Research. Vol.3. pp.88-90. (2015)

[32] Kurtenbach R, Kleffmann J, Niedojadlo A, Wiesen P.: Primary NO 2 emissions and their impact on air quality in traffic environments in Germany. Environmental Sciences Europe. Vol. 24, pp. 21. (2012)

[33] Lamsal LN, Duncan BN, Yoshida Y, Krotkov NA, Pickering KE, Streets DG.: US NO2 trends (2005-2013). EPA Air Quality System (AQS) data versus improved observations from the Ozone Monitoring Instrument (OMI). Atmospheric Environment. Vol. 110, pp. 130-43. (2015)

[34] Reuter M, Buchwitz M, Hilboll A, Richter A, Schneising O, Hilker M.: Decreasing emissions of $\mathrm{NO} x$ relative to CO 2 in East Asia inferred from satellite observations. Nature Geoscience. Vol. 7, pp. 792. (2014)

[35] Dorado M, Ballesteros E, Arnal J, Gomez J, Lopez F.: Exhaust emissions from a Diesel engine fueled with transesterified waste olive oil. Fuel. Vol. 82, pp. 1311-5. (2014) 
[36] Gilbert NL, Woodhouse S, Stieb DM, Brook JR.: Ambient nitrogen dioxide and distance from a major highway. Science of the Total Environment. Vol. 312, pp. 43-6. (2003)

[37] Njoku KL, Rumide TJ, Akinola MO, Adesuyi AA, Jolaoso AO.: Ambient air quality monitoring in metropolitan city of Lagos, Nigeria. Journal of Applied Sciences and Environmental Management. Vol. 20,pp. 178-85. (2016)

[38] Salama KF, Alhajri RF, Al-Anazi AA.: Assessment of air quality in bus terminal stations in Eastern Province, Kingdom of Saudi Arabia. International Journal Of Community Medicine And Public Health. Vol 4, pp. 1413-8. (2017)

[39] Mapoma HWT, Tenthani C, Tsakama M, Kosamu IBM.: Air quality assessment of carbon monoxide, nitrogen dioxide and sulfur dioxide levels in Blantyre. Malawi: a statistical approach to a stationary environmental monitoring station. African Journal of Environmental Science and Technology. Vol. 8,pp. 330-43. (2014)

[40] Shah AS, Lee KK, McAllister DA, Hunter A, Nair H, Whiteley W.: Short term exposure to air pollution and stroke.Vol. 350, pp. 295. (2015)

[41] Franklin BA, Brook R, Pope III CA.: Air pollution and cardiovascular disease. Current problems in cardiology. Vol. 40, pp. 207-38. (2015)

[42] Stojić SS, Stanišić N, Stojić A, Šoštarić A.: Single and combined effects of air pollutants on circulatory and respiratory system-related mortality in Belgrade, Serbia. Journal of Toxicology and Environmental Health, Part A. Vol. 79,pp. 17-27. (2016)

[43] Yusuf KA, Oluwole S, Abdusalam IO, Adewusi GR.: Spatial patterns of urban air pollution in an industrial estate, Lagos, Nigeria. International Journal of Engineering Inventions. Vol. 2, pp. 1-9. (2013)

[44] Greenberg N, Carel R, Derazne E, Tiktinsky A, Tzur D, Portnov B.: Modeling long-term effects attributed to nitrogen dioxide (NO2) and sulfur dioxide (SO2) exposure on asthma morbidity in a nationwide cohort in Israel. Journal of Toxicology and Environmental Health, Part A. Vol. 80, pp. 326-37. (2017)

[45] Greenberg N, Carel RS, Derazne E, Bibi H, Shpriz M, Tzur D,.: Different effects of long-term exposures to $\mathrm{SO} 2$ and $\mathrm{NO} 2$ air pollutants on asthma severity in young adults. Journal of Toxicology and Environmental Health, Part A. Vol. 79, pp. 342-51. (2016)

[46] Hamra GB, Laden F, Cohen AJ, Raaschou-Nielsen O, Brauer M, Loomis D.: Lung cancer and exposure to nitrogen dioxide and traffic. A systematic review and meta-analysis. Environmental health perspectives. Vol. 123, pp. 1107. (2015)

[47] Chen X, Zhang L-w, Huang J-j, Song F-j, Zhang L-p, Qian Z-m:Long-term exposure to urban air pollution and lung cancer mortality. A 12-year cohort study in Northern China. Science of The Total Environment. Vol.571, pp. 855-61. (2016)

[48] Liu Z, Guan D, Wei W, Davis SJ, Ciais P, Bai J: Reduced carbon emission estimates from fossil fuel combustion and cement production in China. Nature. Vol. 524,pp. 335. (2015)

[49] Zhou SS, Lukula S, Chiossone C, Nims RW, Suchmann DB, Ijaz MK.: Assessment of a respiratory face mask for capturing air pollutants and pathogens including human influenza and rhinoviruses. Journal of thoracic disease. Vol. 10, pp. 2059. (2018)

[50] Litman T.: Evaluating public transportation health benefits. Victoria Transport Policy Institute. Pp. 20-19 (2016) 